\title{
Effect of Corticosteroids on the Human
}

\section{Monocyte IgG and Complement Receptors}

\author{
Alan D. Schreiber, Janey Parsons, Patricia McDermott, and \\ Richard A. COOPER \\ From the Hematology-Oncology Section, Department of Medicine, University \\ of Pennsylvania, Philadelphia, Pennsylvania 19104
}

\begin{abstract}
A B S TRACT A quantitative in vitro assay was employed to directly assess the effect of corticosteroids on the IgG and complement receptor function of human mononuclear phagocytic cells. In this system corticosteroids were solubilized with cholesterol-phospholipid sonicated dispersions before exposure to mononuclear cells. Solubilized corticosteroids at concentrations between $10^{-4}$ and $10^{-3} \mathrm{M}$ inhibited both IgG and complement receptor activity in a dose-response fashion. Inhibition was dependent upon the time of interaction of the mononuclear cells with corticosteroids and was halfmaximal by $15 \mathrm{~min}$. The inhibitory effect at all concentrations of hydrocortisone was partially overcome by increasing the number of IgG molecules per erythrocyte. Hydrocortisone also inhibited the binding of erythrocytes coated with both $\operatorname{IgG}$ and $\mathrm{C} 3$, despite the fact that when both were on the erythrocyte surface a synergistic effect on binding to mononuclear cells was observed. At the steroid concentrations employed, the capacity of mononuclear cells to exclude trypan blue and to take up latex particles and neutral red was unaffected. Mineralocorticoids also inhibited receptor activity, but the sex hormones were less effective. These studies demonstrate an effect of steroid hormones on cell membrane receptor function, and they suggest that an inhibition of the recognition system for IgG and $\mathrm{C} 3$ in vivo may explain, in part, the effect of corticosteroids in man.
\end{abstract}

This work was presented in part at the Annual Meeting of the American Society of Hematology, Atlanta, Ga., December, 1974.

Dr. Schreiber is a Leukemia Scholar of the Leukemia Society of America. Dr. Cooper is the recipient of Research Career Development Award AM-38345 from the National Institutes of Health.

Received for publication 14 April 1975 and in revised form 30 June 1975.

\section{INTRODUCTION}

The macrophage IgG and complement receptors are important in host defense $(1,2)$ and are responsible for the increased clearance of immunoglobulin- and complement-coated cells in patients with autoimmune hemolytic anemia and autoimmune thrombocytopenia. Corticosteroids are effective in the treatment of IgG-induced autoimmune hemolysis $(3,4)$. Existing data suggest that this effect results from a decrease in erythrocyte sensitization with antibody by decreasing antibody production $(5,6)$ or by decreasing the binding of antibody to the erythrocyte surface (6).

Previous studies have shown that corticosteroids decrease the clearance of antibody-coated red cells in man $(3,6)$ and rats $(7)$ and IgG- and/or C3-coated red cells in guinea pigs (8). In the latter study Atkinson et al. demonstrated that IgG-sensitized erythrocytes were cleared in corticosteroid-treated guinea pigs as if they had fewer IgG molecules per red cell, suggesting a decreased recognition of immunoglobulin- or complement-coated cells by the macrophages of the reticuloendothelial system of the steroid-treated animal. Indeed recent studies have shown that corticosteroids can affect macrophage (9) and monocyte (10) activity. However, none of these studies have shown an effect of corticosteroids on monocyte or macrophage receptor function. To assess this, we employed a quantitative in vitro model derived from that described by LoBuglio et al. (11), using human erythrocytes and homologous peripheral blood mononuclear phagocytic cells. In order to present poorly soluble steroids in a form which might interact more effectively with the mononuclear cell membrane, we first solubilized corticosteroids with cholesterol-phospholipid sonicated dispersions $(12,13)$. With these tools we examined the effect of corticosteroids on the IgG and $\mathrm{C} 3$ receptors of human mononuclear phagocytic cells. 


\section{METHODS}

Isotonic Veronal-buffered saline, $\mathrm{pH} 7.4$, containing $0.1 \%$ gelatin and $0.0015 \mathrm{M} \mathrm{CaCl}_{2}$ and $0.0005 \mathrm{M} \mathrm{MgCl}_{2}$ (VBS) ${ }^{1}$ and Veronal-buffered saline containing $0.1 \%$ gelatin and $0.01 \mathrm{M}$ ethylenedinitrilotetracetic acid (EDTA buffer) were prepared as previously described $(14,15)$. Rabbit monospecific antiserum to human IgM, IgG, and C3 (Behring Diagnostics, American Hoechst Corp., Somerville, N. J.) ; human anti-Rh D antiserum (Sera-Tec Biologicals, New Brunswick, N. J.) ; human C1 (Cordis Laboratories, Miami, Fla.) ; Hanks' balanced salt solution (HBSS) and Alsever's solution (Grand Island Biological Co., Grand Island, N. Y.) ; trypan blue (Allied Chemical Corp., Morristown, N. J.) ; neutral red (Fisher Scientific Co., King of Prussia, $\mathrm{Pa}$.); and latex particles (The Dow Chemical Company, Indianapolis, Ind.) were obtained as indicated. Peroxidase stain was performed according to Kaplow (16).

Isolation of rabbit IgG anti-human $I g G$, anti-human $C 3$, and complement components. $3 \mathrm{ml}$ of rabbit anti-human IgG or rabbit anti-human C3 antiserum was applied to a $5 \times 100-\mathrm{cm}$ Sephadex G-200 column equilibrated with 0.0035

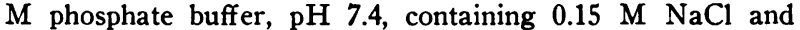
fractionated by upward flow at $15 \mathrm{ml}$ per h. Each IgG fraction was pooled, concentrated to $20 \mathrm{ml}$, absorbed three times with D-positive human erythrocytes, and utilized in the quantitative $\mathrm{IgG}$ and $\mathrm{C} 3$ studies below.

Fresh frozen guinea pig serum was obtained from Rockland, Inc. (Gilbertsville, Pa.). Partially purified guinea pig $\mathrm{C} 2$ and human $\mathrm{C} 1$ were prepared by a modification of established methods $(17,18)$ as were cells coated with hemolytic antibody and the fourth component of complement (EAC4) (19).

Preparation of rabbit IgM anticrythrocyte antiscrum. Erythrocytes obtained from human donors were washed three times in EDTA buffer with removal of the buffy coat and two times with VBS. $1 \mathrm{ml}$ of increasing concentrations of red blood cells (RBC) $\left(1 \times 10^{\circ}-3 \times 10^{\circ} \mathrm{RBC}\right)$ in VBS was injected intravenously 3-4 times per wk over a 3-wk course into the ear vein of New Zealand white rabbits. Bleedings were done 5-10 days after the last injection and $3.5 \mathrm{ml}$ of those antisera with the highest hemagglutinin activity were fractionated by Sephadex G-200 chromatography $(5 \times 100 \mathrm{~cm}$ as above) and the $\operatorname{IgM}$-containing peak pooled so as to contain no detectable IgG by Ouchterlony analysis (20). The $\operatorname{IgM}$ antierythrocyte antibody was stored at $4^{\circ} \mathrm{C}$.

Preparation of human erythrocytes sensitized with human anti-D antisera. Whole blood was obtained from D-positive donors and either diluted threefold with Alsever's solution and held at $4^{\circ} \mathrm{C}$ or diluted with sodium heparin (Riker Laboratories, Inc., Northridge, Calif.) (10 U of heparin per $10 \mathrm{ml}$ whole blood) and used immediately. The diluted whole blood was washed twice with EDTA buffer with removal of the buffy coat, resuspended to $1 \times 10^{8}$ RBC per ml with EDTA buffer, sensitized at $37^{\circ} \mathrm{C}$ with

${ }^{1}$ Abbreviations used in this paper: EDTA buffer, Veronal-buffered saline containing $0.1 \%$ gelatin and $0.01 \mathrm{M}$ ethylenedinitrilotetracetic acid; EIgMC3, human erythrocytes sensitized with IgM and C3; HBSS, Hanks' balanced salt solution; HC, cholesterol-phospholipid mixtures containing hydrocortisone; RBC, red blood cells; VBS, isotonic Veronal-buffered saline, $\mathrm{pH} 7.4$, containing $0.1 \%$ gelatin and $0.0015 \mathrm{M} \mathrm{CaCl}_{2}$ and $0.0005 \mathrm{M} \mathrm{Mgl}_{2}$. an equal volume of anti-D antiserum diluted in EDTA buffer, washed once with EDTA buffer and twice with HBSS, and resuspended with HBSS to a final concentration of $5 \times 10^{7}$ erythrocytes per $\mathrm{ml}$. In all experiments utilizing sensitized red cells, control erythrocytes were prepared by exposing washed erythrocytes to EDTA buffer at $37^{\circ} \mathrm{C}$ in the absence of antiserum. For experiments examining mononuclear cell binding of IgG-sensitized erythrocytes, red cells were radiolabeled with $\left[{ }^{51} \mathrm{Cr}\right]$ sodium dichromate (100 $\mu \mathrm{Ci}$ per $\mathrm{ml}$ of whole blood) (New England Nuclear, Boston, Mass.) by standard techniques (21) before sensitization. Hemagglutination titers were performed by a microtiter technique. $2.5 \times 10^{8}$ washed, anti-D-sensitized human erythrocytes in a volume of $25 \mu \mathrm{l}$ were added to $50 \mu \mathrm{l}$ of serial threefold falling dilutions of monospecific rabbit anti-human IgG or anti-human IgM antiserum diluted in EDTA buffer. The suspensions were mixed and incubated at $37^{\circ} \mathrm{C}$ for $30 \mathrm{~min}$ and at room temperature for an additional $30 \mathrm{~min}$ and examined for agglutination. In all experiments there was no detectable agglutination of anti-D-sensitized erythrocytes incubated with EDTA buffer alone or with anti-IgM antisera, while marked agglutination was seen with greater than $1: 1,000$ dilution of anti-IgG antisera.

Preparation of human erythrocytes sensitized with IgM and $C 3$ (EIgMC3). Whole human blood obtained and washed with removal of the buffy coat as above was resuspended to $1 \times 10^{8} \mathrm{RBC}$ per ml with EDTA buffer and sensitized at $37^{\circ} \mathrm{C}$ with an equal volume of IgM antierythrocyte antibody diluted in EDTA buffer, washed once with EDTA buffer, and washed twice with HBSS. $5 \times 10^{7}$ of these RBC were incubated with $1: 16$ dilution of fresh autologous serum as a source of $\mathrm{C} 3$ at $37^{\circ} \mathrm{C}$ for $15 \mathrm{~min}$, washed three times with HBSS, and resuspended to $5 \times 10^{7} \mathrm{RBC}$ per $\mathrm{ml}$ with HBSS. The number of IgM and $\mathrm{C} 3$ molecules per EIgMC3 was determined by $\mathrm{C} 1$ fixation and transfer (see below).

In all experiments utilizing EIgMC3, control erythrocytes sensitized with $\operatorname{IgM}$ alone without exposure to serum, as well as erythrocytes exposed to serum in the absence of IgM antibody, were employed. For experiments examining mononuclear cell binding of EIgMC3, red cells were radiolabeled with $\left[{ }^{51} \mathrm{Cr}\right]$ sodium dichromate $(100 \mu \mathrm{Ci}$ per $\mathrm{ml}$ of whole blood) before sensitization. Erythrocytes sensitized with subagglutinating concentrations of $\operatorname{IgM}$ antierythrocyte antibody were not agglutinated when incubated with anti-IgG antiserum. 30 molecules of IgM per RBC, as determined by $\mathrm{Cl}$ fixation and transfer (see below), were sufficient to cause detectable direct agglutination.

Quantitation of the number of immunoglobulin or C3 moleculcs per erythrocyte. The $\mathrm{Cl}$ fixation and transfer method was used to determine the average number of $\mathrm{IgG}$ molecules per erythrocyte in the sensitized erythrocyte population $(22,15)$. This technique provides a minimum estimate of the number of immunoglobulin molecules per cell (22). D-positive erythrocytes suspended in EDTA buffer were sensitized with twofold falling dilutions of human anti-D antiserum diluted in EDTA buffer as indicated in the preparation of IgG-sensitized erythrocytes. The average number of IgG C1-fixing sites generated was determined after sensitization with rabbit IgG anti-human IgG and typical dose-response curves with a slope of 1.0 were obtained, directly relating the number of $\mathrm{C} 1$-fixing sites to the number of IgG molecules per erythrocyte (23, 24). Similar results were obtained with three different preparations of anti-IgG. In all experiments erythrocytes 
were sensitized with approximately $900 \mathrm{IgG}$ molecules per RBC. At all concentrations of IgG per red cell examined no C1-fixing sites were generated in the absence of antiIgG.

The number of IgM molecules per RBC was determined by direct $\mathrm{C} 1$ fixation and transfer after sensitization of human erythrocytes suspended in EDTA buffer with twofold falling dilutions of $\mathrm{IgM}$ antierythrocyte antibody diluted in EDTA buffer $(22,15)$. Typical dose-response curves were obtained with a slope of 1.0. The slope of 1.0 has been taken to indicate that one $\operatorname{IgM}$ molecule is capable of fixing one molecule of $\mathrm{Cl}$ (23). In all experiments using IgM antibody, erythrocytes were sensitized with approximately 120 molecules of IgM per RBC.

The number of $\mathrm{C} 3$ molecules per EIgMC3 was estimated by determining the number of $\mathrm{C} 1$-fixing sites generated after exposure to 2-mercaptoethanol and IgG anti-C3 (25). Erythrocytes sensitized with 120 molecules of IgM antibody were incubated with serial twofold falling dilutions of autologous serum as a source of $\mathrm{C} 3$ for $15 \mathrm{~min}$ at $37^{\circ} \mathrm{C}$, washed once with VBS, incubated with $0.05 \mathrm{M}$ 2-mercaptoethanol for $30 \mathrm{~min}$ at $37^{\circ} \mathrm{C}$, washed twice in EDTA buffer, and incubated with an optimal concentration of anti-C3 $(25,26)$ before $\mathrm{C} 1$ fixation and transfer. Typical dose-response curves with a slope of 1.0 directly relating the number of $\mathrm{C} 1$-fixing sites generated by anti-C3 to the concentration of serum employed were obtained. The number of C1-fixing sites generated by anti-C3 relates to a minimum estimate of the absolute number of C3 molecules per $\operatorname{RBC}(25,26)$.

In all experiments using EIgMC3, erythrocytes were sensitized with 120 molecules of IgM and a $1: 16$ concentration of serum. This concentration of serum generated approximately 2,500 C1-fixing sites with anti-C3. This method of analysis of cell-bound C3 detects both $\mathrm{C} 3 \mathrm{~b}$ and its major degradation product, C3d. IgM-sensitized erythrocytes were exposed to autologous serum for $15 \mathrm{~min}$ at $37^{\circ} \mathrm{C}$; after this incubation period, one would expect most of the cell bound $\mathrm{C} 3$ to be in the form C3b (27). EIgMC3 were immune adherence positive.

Immune adherence assay. Immune adherence assays were performed as previously described (27). $5 \mu \mathrm{l}$ of 3.3 $\times 10^{7}$ IgM-sensitized erythrocytes or EIgMC3 were placed in $20 \mu 1$ of VBS. $50 \mu 1$ of $5 \times 10^{7}$ washed human erythrocytes (possessing the immune adherence receptor) were added to each well. The preparations were mixed and incubated for $30 \mathrm{~min}$ at $37^{\circ} \mathrm{C}$ and immune adherence activity examined at 15 and $30 \mathrm{~min}$.

Preparation of mononuclear cell monolayers. Mononuclear cell monolayers were prepared by the method of LoBuglio et al. (11) modified as below. Whole blood was obtained from normal human donors, anticoagulated with sodium heparin (10 $\mathrm{U}$ per $\mathrm{ml}$ of whole blood), and applied to a Ficoll-Hypaque density gradient (28). The mononuclear cell layer was harvested, diluted with HBSS to $1 \times 10^{\circ}$ mononuclear cells per $\mathrm{ml}$, and $1 \mathrm{ml}$ was placed in replicate $35-\mathrm{mm}$ plastic tissue culture dishes (Falcon Plastics, Oxnard, Calif.) for $45 \mathrm{~min}$ at room temperature; nonadherent cells were decanted and the adherent cells were washed five times with HBSS. In all experiments monolayer plates contained greater than $97 \%$ mononuclear cells of which approximately $80 \%$ were peroxidase positive. Approximately $90 \%$ of cells morphologically appeared to be monocytes when stained with Wright's-Giemsa and examined by light microscopy. The number of mononuclear cells per monolayer was quantitated by light microscopy with a Kpl-W 125 Zeiss microscopy eyepiece (Carl Zeiss, Inc., New York). The mean number of mononuclear cells per field $\left(2.5 \times 10^{-2} \mathrm{~mm}^{2}\right)$ was determined by examining 100 consecutive fields. The number of mononuclear cells per monolayer $\left(8.6 \times 10^{2} \mathrm{~mm}^{2}\right)$ was then calculated. Trypan blure exclusion was performed by standard techniques.

Mononuclear cell binding of radiolabeled, IgG-sensitized erythrocytes was achieved by incubating $1 \mathrm{ml}\left(5 \times 10^{7}\right.$ per $\mathrm{ml}$ ) of unsensitized or IgG-sensitized erythrocytes with each monolayer for $2 \mathrm{~h}$ at $37^{\circ} \mathrm{C}$, decanting unbound erythrocytes and washing five times with HBSS; the monolayers were then lysed with $\mathrm{H}_{2} \mathrm{O}$ and the lysate was assayed for radioactivity in a gamma counter (Nuclear Chicago, Searle Analytic, Inc., Des Plaines, Ill.) or air-dried and stained with Wright's-Giemsa for light microscopy. All experiments were performed in triplicate. Less than $1 \%$ of the mononuclear cells bound red cells when incubated with unsensitized erythrocytes, and the ratio of unsensitized to sensitized red cells bound per monolayer was 1:10 and usually $1: 20$ in all experiments. Inhibition of mononuclear monolayer cell binding of sensitized erythrocytes was determined in all experiments as follows: $\{1-[\mathrm{cpm}$ of lysate (monolayer incubated with steroid)/cpm of lysate (monolayer incubated with buffer] $\} \times 100$.

Mononuclear cell binding of EIgMC3 was assessed in a similar manner by incubated mononuclear monolayer cells at $37^{\circ} \mathrm{C}$ for $90 \mathrm{~min}$ with radiolabeled EIgMC3 $\left(5 \times 10^{\prime}\right.$ $\mathrm{RBC})$. The number of bound erythrocytes was determined as in the IgG receptor assay above.

Solubilization of steroids. Steroids were solubilized in cholesterol-phospholipid mixtures by a modification of the method of Bruckdorfer et al. (12). $23 \mathrm{mg}$ of unesterified cholesterol (Sigma Chemical Co., St. Louis, Mo.) and 40 $\mathrm{mg}$ of the phospholipid 1,2-dipalmitoyl lecithin (Grand Island Biological Co.) were added with $5 \mathrm{mg}$ of steroid to $10 \mathrm{ml}$ of $0.15 \mathrm{M} \mathrm{NaCl}$. The mixture was placed in a fluted metal container surrounded by an ice slurry and subjected to $70 \mathrm{~W}$ for $60 \mathrm{~min}$ with a Branson sonifier (Heat Systems-Ultrasonics, Inc., Plainview, N. Y.) using a standard tip. All sonicated cholesterol-phospholipid mixtures were centrifuged at $21,800 \mathrm{~g}$ for $30 \mathrm{~min}$ to remove sedimented insoluble material. Cholesterol-phospholipid mixtures containing hydrocortisone are designated "HC." Such cholesterol-phospholipid mixtures have been previously shown to cause no change in red cell or platelet cholesterol:phospholipid ratio $(29,30)$.

Ingestion of neutral red or latex particles. Neutral red (0.1\%) was diluted $1: 10$ with HBSS, and $1 \mathrm{ml}$ was incubated at room temperature for $10 \mathrm{~min}$ with replicate monolayers. A cover slip was added and the percentage of cells demonstrating neutral red uptake determined by light microscopy. In each experiment 100 consecutive cells were examined. Phagocytosis of latex particles was determined by incubating $1 \mathrm{ml}$ of $1.0-\mu \mathrm{m}$ latex particles $\left(5 \times 10^{7} / \mathrm{ml}\right)$ in HBSS with replicate monolayers for $1 \mathrm{~h}$ at $37^{\circ} \mathrm{C}$ and the percentage mononuclear cells containing $>4$ latex particles per cell determined by counting 100 consecutive cells in each experiment under phase microscopy.

Steroids. Hydrocortisone, deoxycorticosterone, $\beta$-estradiol, testosterone, progesterone hydrocortisone phosphate, hydrocortisone acetate, hydrocortisone succinate, prednisone, dexamethasone, and aldosterone were obtained from Sigma Chemical Co.

Statistics. The results are expressed as mean \pm SEM. Comparisons were evaluated by using Student's $t$ test for unpaired samples. 


\section{RESULTS}

The effect of $\mathrm{HC}$ on mononuclear cell $\mathrm{IgG}$ receptor activity was first examined by incubating IgG (anti-D) sensitized erythrocytes with mononuclear cells in the presence of $1 \mathrm{ml}$ of $8 \times 10^{-4} \mathrm{M} \mathrm{HC}$ or buffer (Fig. 1). $\mathrm{HC}$ caused a $66 \%$ inhibition of the binding of sensitized erythrocytes to the mononuclear cell monolayer. Preincubation of the monolayers with $\mathrm{HC}$ for $30 \mathrm{~min}$ at $37^{\circ} \mathrm{C}$ before the introduction of IgG-sensitized erythrocytes increased this inhibition to $97 \%$. Washing the monolayers after $30 \mathrm{~min}$ of preincubation with $\mathrm{HC}$ did not diminish the capacity of $\mathrm{HC}$ to inhibit erythrocyte binding. In all subsequent experiments, monolayers were washed three times after a 30 -min preincubation with $\mathrm{HC}$. Although $\mathrm{HC}$ inhibited the attachment of IgGcoated red cells, it did not cause the release of mononuclear-cell-bound erythrocytes from their mononuclear cell attachment site when added for $30 \mathrm{~min}$ at $37^{\circ} \mathrm{C}$ (Fig. 1, D).

To further assess the effect of $\mathrm{HC}$, monolayers were preincubated with $4 \times 10^{-4} \mathrm{M}$ and $8 \times 10^{-4} \mathrm{M} \mathrm{HC}$ for varying time intervals (Fig. 2). No inhibition of IgGcoated erythrocyte binding was observed with up to 5 min of preincubation with $8 \times 10^{-4} \mathrm{M}$ or up to $15 \mathrm{~min}$ of preincubation with $4 \times 10^{-4} \mathrm{M} H C$. Thereafter, a progressive inhibition of the capacity of the mononuclear cells to bind IgG-sensitized erythrocytes was observed.

The effect of hydrocortisone concentration on the inhibition of mononuclear cell IgG receptor activity was examined in two ways (Fig. 3). First, hydrocortisone was solubilized with cholesterol-phospholipid mixtures (HC) and the effect of varying dilutions of $\mathrm{HC}$ with buffer was studied. In addition, cholesterol-phospholipid

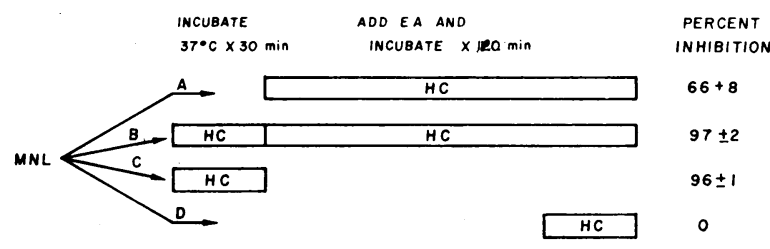

FIgURE 1 Inhibition of IgG receptor activity by $8 \times 10^{-4}$ $M$ hydrocortisone (HC). Four experiments (A-D) are shown. In each experiment all additions were to replicate mononuclear cell monolayers (MNL). In all experiments erythrocytes were sensitized with $900 \mathrm{IgG}$ per RBC (EA). In exp. $\mathrm{A}, \mathrm{HC}$ was added with $\mathrm{EA}$ for $120 \mathrm{~min}$ at $37^{\circ} \mathrm{C}$. In exp. $\mathrm{B}, \mathrm{MNL}$. were preincubated for $30 \mathrm{~min}$ at $37^{\circ} \mathrm{C}$ with $\mathrm{HC}$ before the addition of EA. In exp. C, MNL were preincubated with $\mathrm{HC}$ and washed three times before the introduction of $\mathrm{EA}$ for $120 \mathrm{~min}$ at $37^{\circ} \mathrm{C}$. In exp. D, MNL were first incubated with EA for $90 \mathrm{~min}$ at $37^{\circ} \mathrm{C}$, washed three times- and then incubated with $\mathrm{HC}$ for 30 $\min$ at $37^{\circ} \mathrm{C}$ to assess displacement of EA from mononuclear cells by $\mathrm{HC}$.

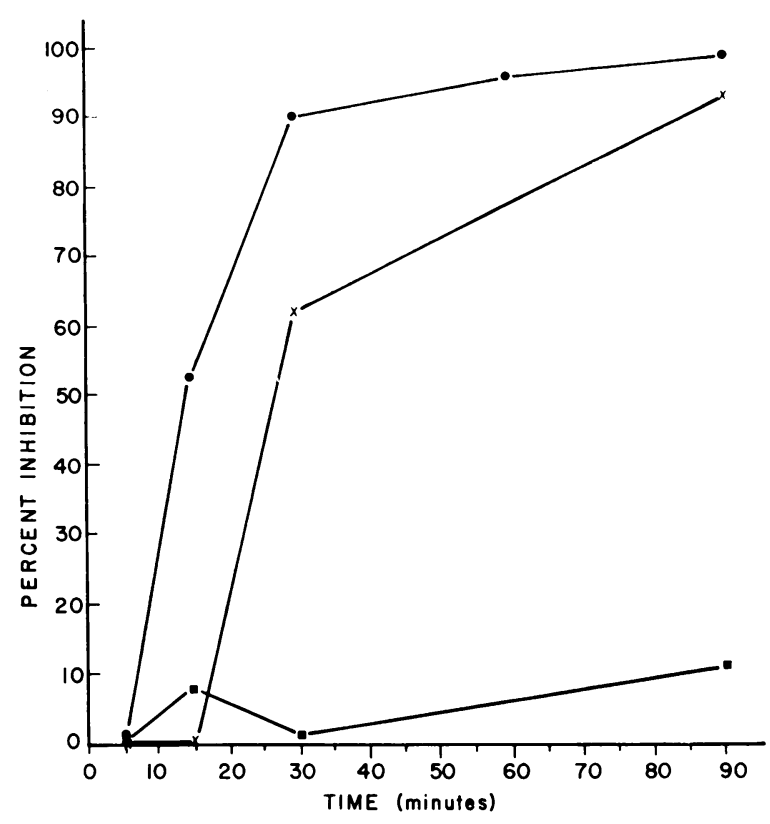

FIGURE 2 Kinetics of inhibition of IgG receptor activity by hydrocortisone. represents the effect of $8 \times 10^{-4} \mathrm{M}$ $\mathrm{HC}$ and $X$ the effect of $4 \times 10^{-4} \mathrm{M}$ HC. $\square$ represents the effect of cholesterol-phospholipid mixtures without hydrocortisone.

mixtures were prepared with a constant amount of cholesterol-phospholipid and a varying amount of hydrocortisone. Little inhibition was seen after preincubation of the mononuclear cells with hydrocortisone at concentrations up to $2.5 \times 10^{-5} \mathrm{M}$. Thereafter, inhibition was progressive, the half-maximal point being at approximately $2 \times 10^{-4} \mathrm{M}$. Preincubation with solubilized cholesterol-phospholipid mixtures without hydrocortisone inhibited the binding of sensitized erythrocytes $<10 \%$.

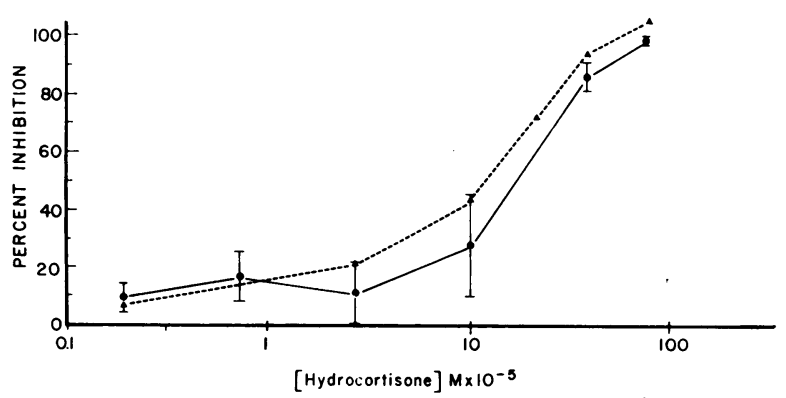

FIGURE 3 Inhibition of IgG receptor activity by hydrocortisone. $\Delta$ represents cholesterol-phospholipid mixtures containing a constant amount of cholesterol and phospholipid but different concentrations of hydrocortisone. - represents twofold falling dilutions of a mixture containing cholesterol $(1.4 \mathrm{mg} / \mathrm{ml})$, phospholipid $(2.4 \mathrm{mg} / \mathrm{ml})$, and $\mathrm{HC}\left(8 \times 10^{-4} \mathrm{M}\right)$. 


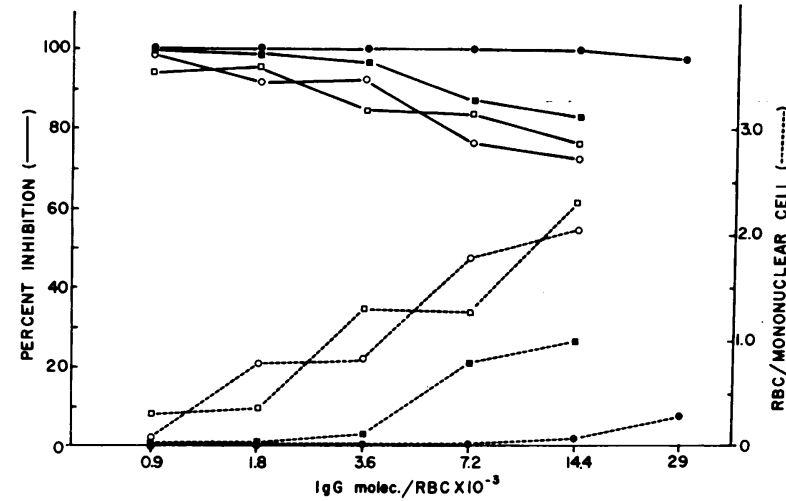

FIGURE 4 IgG receptor inhibition by hydrocortisone: effect of increasing IgG/RBC. Monolayer cells were preincubated with $8 \times 10^{-4} \mathrm{M} \mathrm{HC}(\bullet), 4 \times 10^{-4} \mathrm{M} \mathrm{HC}(\square)$, $3 \times 10^{-4} \mathrm{M} H C(\square)$, and $2 \times 10^{-4} \mathrm{M} \mathrm{HC}$ (O). With increased IgG per erythrocyte the inhibitory effect of low concentrations of $\mathrm{HC}$ was partially overcome.

There is evidence that erythrocytes more heavily sensitized with IgG may still be cleared in vivo in corticosteroid-treated animals (8). Therefore, the effect of the number of IgG molecules per red cell on the ability of $\mathrm{HC}$-treated mononuclear cells to detect IgG-coated erythrocytes was examined. With increasing numbers of IgG molecules per red cell there was a progressive decrease in the inhibitory effect of HC (Fig. 4). At all concentrations of $\mathrm{HC}$ examined $\left(2-8 \times 10^{-4} \mathrm{M}\right)$, inhibition was achieved at each level of IgG sensitization in a dose-dependent fashion.

The effect of $\mathrm{HC}$ on the mononuclear cell $\mathrm{C} 3$ receptor was examined in a similar fashion. When mononuclear cells preincubated with $\mathrm{HC}$ were incubated with red cells coated with $\mathrm{C} 3$, results similar to those obtained with IgG-coated cells were observed (Fig. 5). Inhibition was $90 \%$ at $\mathrm{HC}$ concentrations of $8 \times 10^{-4} \mathrm{M}$ and approximately half-maximal at $1 \times 10^{-4} \mathrm{M}$ HC. Neither IgMsensitized erythrocytes not incubated with serum nor unsensitized erythrocytes incubated in serum were bound to the monolayers.

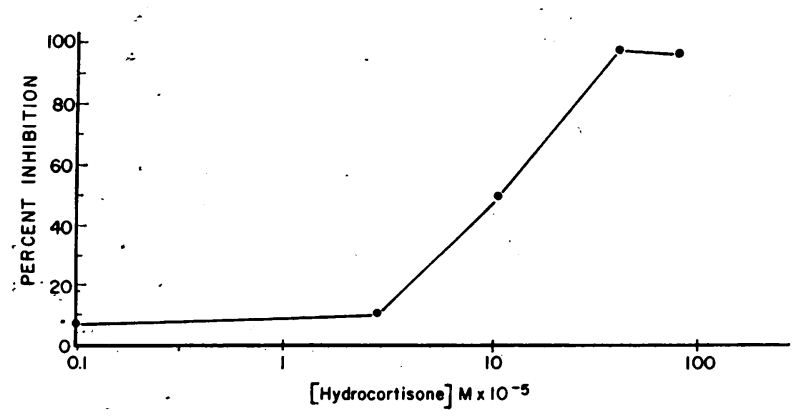

Figure 5 Inhibition of monocyte C3 receptor by hydrocortisone.
TABLE I

Inhibition of Mononuclear Monolayer Cell Binding of Erythrocytes Coated with $\mathrm{IgG}$ and/or Complement by $\mathrm{HC}$

\begin{tabular}{lccc}
\hline & \multicolumn{3}{c}{$\begin{array}{c}\text { Red cells bound per mononuclear cell } \\
\text { preincubated with: }\end{array}$} \\
\cline { 2 - 4 } & \multicolumn{3}{c}{ HC } \\
\cline { 2 - 4 } RBC coated with: & $4 \times 10^{-4} \mathrm{M}$ & $3 \times 10^{-4} \mathrm{M}$ & Buffer \\
\hline IgG & 0.1 & 0.3 & 2.4 \\
C3 & 0.1 & 0.2 & 2.5 \\
IgG + C3 & 0.4 & 1.5 & 7.2 \\
\hline
\end{tabular}

The average number of red cells bound per mononuclear cell was calculated from the radioactivity $\left({ }^{51} \mathrm{Cr}\right)$ per monolayer $\left(1 \times 10^{5}\right.$ mononuclear cells $)$.

The capacity of $\mathrm{HC}$ to inhibit erythrocytes sensitized with both IgG and $\mathrm{C} 3$ was also examined (Table I). IgG-sensitized erythrocytes were coated with $\mathrm{C} 3$ and the binding to monolayers compared to that of erythrocytes sensitized with either C3 or IgG alone. The number of IgG and C3 molecules per erythrocyte was the same whether erythrocytes were sensitized with both IgG and $\mathrm{C} 3$ or whether they were sensitized with $\mathrm{IgG}$ or $\mathrm{C} 3$ alone. In order to directly compare the number of IgG- with the number of C3-coated red cells bound per mononuclear cell, the results are expressed in terms of red cells per mononuclear cell. Concentrations of IgG (900 IgG C1fixing sites) and C3 (1,250 C1-fixing sites) per erythrocyte were selected that caused equal numbers of erythrocytes to be bound per mononuclear cell. The effect of IgG plus $\mathrm{C} 3$ on the binding of erythrocytes to mononuclear cells appeared to be synergistic. $\mathrm{HC}$ ( 3 and $4 \times 10^{-4}$ M) pretreatment inhibited mononuclear cell binding of erythrocytes sensitized with both IgG and C3; however, this inhibition was less marked than that seen with either $\mathrm{IgG}$ or $\mathrm{C} 3$ alone.

The effect of preincubation with $\mathrm{HC}\left(8 \times 10^{-4} \mathrm{M}\right)$ on mononuclear cell function is shown in Table II. HC did not diminish the number of mononuclear cells per monolayer, nor did it increase the percentage of mononuclear cells capable of excluding trypan blue. The capacity of mononuclear cells to take up neutral red or latex particles was also unaffected.

The capacity of other steroid hormones to influence the IgG receptor activity of mononuclear cells was also examined. Monolayers were preincubated with each steroid $(300 \mu \mathrm{g} / \mathrm{ml})$ solubilized in cholesterol-phospholipid mixtures (Table III). As with $\mathrm{HC}$, the corticosteroid derivatives prednisone and dexamethasone markedly inhibited the binding of IgG-coated red cells. Mineralocorticoids also caused a marked inhibition of IgG receptor activity, but the sex hormones had a less profound 
TABLE II

Effect of $8 \times 10^{-4} \mathrm{MHC}$ on the Mononuclear Monolayer

\begin{tabular}{lcccc}
\hline & $\begin{array}{c}\text { Trypan blue } \\
\text { uptake }\end{array}$ & $\begin{array}{c}\text { Mononuclear } \\
\text { cells per } \\
\text { monolayer* }\end{array}$ & $\begin{array}{c}\text { Neutral red } \\
\text { uptake }\end{array}$ & $\begin{array}{c}\text { Latex uptake } \\
(>4 \text { particles/ } \\
\text { cell) }\end{array}$ \\
\hline & $\%$ & & $\%$ & $\%$ \\
CPM + hydrocortisone & $8 \pm 5.5$ & $1.1 \times 10^{5}$ & $94 \pm 1.8$ & $78 \pm 5.1$ \\
CPM & $9 \pm 1.0$ & $1.1 \times 10^{5}$ & $95 \pm 1.2$ & $68 \pm 4.6$ \\
Saline & $6 \pm 5.1$ & $1.2 \times 10^{5}$ & $97 \pm 1.3$ & $82 \pm 12.0$ \\
\hline
\end{tabular}

CPM, cholesterol-phospholipid mixtures without hydrocortisone; CPM + hydrocortisone, cholesterol phospholipid mixtures solubilized with $8 \times 10^{-4} \mathrm{M}$ hydrocortisone.

* Mean of quadruplicate monolayers for each experimental condition (representative experiment).

inhibitory effect. Water-soluble derivatives of hydrocortisone had a variable effect. Hydrocortisone hemisuccinate was equivalent to hydrocortisone, whereas hydrocortisone phosphate and hydrocortisone acetate had significantly less inhibitory activity.

\section{DISCUSSION}

These studies demonstrate an effect of steroid hormones on the $\operatorname{IgG}$ and $\mathrm{C} 3$ receptor function of human peripheral blood mononuclear phagocytic cells. Previous studies in steroid-treated animals suggested a decreased recognition of IgG- and complement-coated cells by macrophages $(9,10)$. To assess this in vitro we examined the human peripheral blood mononuclear phagocytic cell, a cell closely related to the tissue macrophage (31), and employed a homologous in vitro model which permits quantitative evaluation of $\operatorname{IgG}$ and $\mathrm{C} 3$ receptor function.

TABLE III

IgG Receptor Inhibition by Steroids $(300 \mu \mathrm{g} / \mathrm{ml})$

\begin{tabular}{lcc}
\hline & Molarity & $\begin{array}{c}\text { Percent } \\
\text { inhibition }\end{array}$ \\
\hline Hydrocortisone & $8 \times 10^{-4}$ & $96 \pm 1.2$ \\
Prednisone & $8 \times 10^{-4}$ & $93 \pm 7.5$ \\
Dexamethasone & $8 \times 10^{-4}$ & $80 \pm 16.0$ \\
Mineralocorticoids & $8 \times 10^{-4}$ & $89 \pm 3.5$ \\
$\quad$ Aldosterone & $9 \times 10^{-4}$ & $72 \pm 9.4$ \\
$\quad$ Deoxycorticosterone & $1 \times 10^{-3}$ & $29 \pm 1.0$ \\
Sex hormones & $1 \times 10^{-3}$ & $46 \pm 2.5$ \\
$\quad \beta$-Estradiol & $1 \times 10^{-3}$ & $43 \pm 12.0$ \\
$\quad$ Testosterone & $6 \times 10^{-4}$ & $100 \pm 1.0$ \\
$\quad$ Progesterone & $6 \times 10^{-4}$ & $67 \pm 13.8$ \\
Hydrocortisone succinate & $7 \times 10^{-4}$ & $33 \pm 15.9$ \\
Hydrocortisone phosphate & $8 \times 10^{-4}$ & $9 \pm 3.4$ \\
Hydrocortisone acetate & & \\
Cholesterol & &
\end{tabular}

In vitro studies involving steroid hormones are limited by the low solubility of steroids in aqueous solutions. However, steroids may be solubilized by sonication with cholesterol-phospholipid mixtures (12). Mixtures with a cholesterol: phospholipid molar ratio of 1.0 have been used in our studies, since it is known that this proportion does not affect either the lipid composition or the function of other human peripheral blood cell membranes $(29,30)$.

Solubilized hydrocortisone (HC) inhibited mononuclear cell $\mathrm{IgG}$ and $\mathrm{C} 3$ receptor function in a dose-response fashion (Figs. 3 and 5). The effect of $\mathrm{HC}$ was directly on the mononuclear cell monolayer, as it was not reversed by washing (Fig. 1) and was dependent upon the time of interaction of $\mathrm{HC}$ with the mononuclear cells (Fig. 2). However, once IgG-coated erythrocytes were bound to their mononuclear cell attachment site, HC did not cause their removal (Fig. 1).

Mononuclear cells were viable as determined by trypan blue exclusion and at the concentrations of $\mathrm{HC}$ examined nonimmune phagocytosis of latex particles and neutral red was unaffected while IgG receptor activity was markedly inhibited (Table II). Whether higher concentrations of solubilized hydrocortisone affect nonimmune phagocytosis of monolayer cells as well, as has been demonstrated by others with steroids in animal models $(32,33,7)$, remains to be determined.

Our data demonstrate that $\mathrm{HC}$ also inhibits the binding of erythrocytes coated wtih complement whether or not IgG is also present. Erythrocytes with $\mathrm{C} 3 \mathrm{~b}$ on their surface are immune adherence positive $(34,35,27)$ and our complement-coated red cells were positive in the immune adherence reaction. C3b-coated erythrocytes bind to a macrophage receptor which is similar to and perhaps identical with (36) the immune adherence receptor. Recently, evidence has been presented for a receptor for the fourth component of complement ( $C 4 b)$ on human polymorphonuclear leukocytes (37) and

1194 A. D. Schreiber, J. Parsons, P. McDermott, and R. A. Cooper 
monocytes (38). In this study we have not distinguished between $\mathrm{C} 3 \mathrm{~b}$ and $\mathrm{C} 4 \mathrm{~b}$, and thus the relative contribution of each in binding erythrocytes to the mononuclear monolayer cells is undetermined.

In our system, as has been previously described (15, $39,40)$, complement is required for the binding of $\mathrm{IgM}$ sensitized cells to macrophages, and at the concentration of $\mathrm{IgM}$ employed we have confirmed the absence of a receptor for IgM on human peripheral blood monocytes. The clearance of erythrocytes in IgM-induced hemolytic anemia in man (cold agglutinin disease) is dependent upon the macrophage complement receptors $(26,15,27)$. Corticosteroid therapy is not as effective in cold agglutinin disease as in warm antibody ( $\mathrm{IgG}$ ) autoimmune hemolytic anemia $(3,4)$. Corticosteroids, however, have been demonstrated to decrease the clearance of IgM-sensitized cells in an animal model (8). This apparent discrepancy may relate to the large number of C3b molecules per erythrocyte in cold hemagglutin disease or to species differences in the systems involved.

Our data are in keeping with the in vivo clinical (6) and experimental (8) evidence that the improved red blood cell survival with corticosteroids can be overcome when the concentration of IgG per erythrocyte is increased. Increasing the number of IgG molecules per erythrocyte resulted in increased numbers of erythrocytes bound per HC-treated mononuclear cell at all concentrations of $\mathrm{HC}$ (Fig. 4). Furthermore, with increased numbers of IgG per erythrocyte the percentage inhibition observed at each concentration of $\mathrm{HC}$ became less marked.

Erythrocytes coated with IgG and complement are cleared more rapidly in vivo than erythrocytes coated with $\operatorname{IgG}$ alone $(15,41,42)$, and corticosteroid treatment is less effective in improving the clearance of cells sensitized with both IgG and C3 $(8,41)$. This is consistant with our observation that erythrocytes coated with both IgG and C3 bind more effectively to $\mathrm{HC}$ treated mononuclear cells than red cells coated with either IgG or C3 (Table I).

Mononuclear cell binding of IgG- and C3-coated cells is greater than the additive binding observed with cells coated with either IgG or C3 (Table I). This suggests a synergistic interaction between the IgG and complement receptors. Mantovani et al. previously showed that complement markedly enhanced the binding of IgG-sensitized cells to mouse peritoneal macrophages (40). However, they did not examine macrophage binding of complement-coated cells alone. Huber et al. studied the human monocyte $\operatorname{IgG}$ and $\mathrm{C} 3$ receptors in a heterologous system which employed sheep red blood cells and rabbit IgG antibody. Their studies revealed a cooperative interaction between the monocyte $\mathrm{IgG}$ and C3 receptors in phagocytosis (39).
Although not assessed directly, it appears that the locus of action of steroid hormones in these studies is at the membrane level. While a direct effect of steroid hormones on membranes has been postulated, it has been difficult to establish (43). A wide range of steroids can be incorporated into natural and artificial lipid membranes $(44,45)$; however, there does not appear to be a constant relationship between the ability of a steroid to do so and the structural features of the steroid molecule. The effect of steroids on membranes has been observed most vividly in their ability to stabilize or labilize artificial lipid membrane vesicles $(46,47)$. In addition, some steroid hormones bind to the membrane proteins of red cells and this appears to underlie the effect of progesterone on the storage of human red cells (48). It is unclear whether the effect which we have observed results from a direct effect on membrane lipids, a direct effect on membrane proteins (e.g., the receptors themselves), or an indirect effect on the membrane exerted from within the cell.

Rinehardt et al. recently examined the effect of corticosteroids in vitro (10) and in vivo (49) on the human peripheral blood monocyte. They observed no inhibition of $\mathrm{IgG}$ receptor activity and the complement receptor was not studied. However, their study differs in that monocytes were not preincubated with steroid and they did not employ corticosteroids in a lipid, membrane-soluble form. Additionally, our studies indicate that inhibition of $\operatorname{IgG}$ receptor activity is dependent upon the concentration of hydrocortisone as well as the number of $\mathrm{IgG}$ molecules per erythrocyte. The concentration of hydrocortisone employed in our studies are similar to plasma steroid levels that have been achieved in vivo $(50,51)$. Nonetheless, whether hydrocortisone can directly affect IgG receptor function in vivo remains to be determined.

\section{ACKNOWLEDGMENTS}

We wish to thank Dr. Richard Root of the Department of Medicine at the Hospital of the University of Pennsylvania for reviewing the manuscript.

This work was supported by National Institutes of Health grants CA-15236, CA-11630, and HL-06019.

\section{REFERENCES}

1. Stossel, T. P. 1974. Phagocytosis. N. Engl. J. Med. 290: 717-723, 774-780, 833-839.

2. Frank, M. M., A. D. Schreiber, and J. P. Atkinson. 1975. Studies of the interaction of antibodies, complement and macrophages in the immune clearance of erythrocytes. In The Phagocytic Cell in Host Resistance. J. Ballanti and D. H. Dayton, editors. Raven Press, New York.

3. Dacie, J. V. 1962. The Haemolytic Anaemias, Congenital and Acquired. Part II. The Autoimmune Haemolytic Anaemias. Grune \& Stratton, Inc., New York. 2nd edition. 
4. Leddy, J. P., and S. N. Swisher. 1971. Acquired immune hemolytic disorders. Immunological Diseases. M. Samter, editor. Little, Brown and Company, Boston. 2nd edition. 2: 1083-1110.

5. Claman, H. N. 1972. Corticosteroids and lymphoid cells. N. Engl. J. Med. 287: 388-397.

6. Rosse, W. F. 1971. Quantitative immunology of immune hemolytic anemia. 1l. The relationship of cellbound antibody to hemolysis and the effect of treatment. J. Clin. Invest. 50: 734-743.

7. Kaplan, M. E., and J. H. Jandl. 1961. Inhibition of red cell sequestration by cortisone. J. Exp. Med. 114: 921937.

8. Atkinson, J. P., A. D. Schreiber, and M. M. Frank. 1973. Effects of corticosteroids and splenectomy on the immune clearance and destruction of erythrocytes. $J$. Clin. Invest. 52: 1509-1517.

9. Weston, W. L., H. N. Claman, and G. G. Krueger. 1973. Site of action of cortisol in cellular immunity. $J$. Immunol. 110: 880-883.

10. Rinehardt, J. J., S. P. Balcerzak, A. L. Sagone, and A. F. LoBuglio. 1974. Effects of corticosteroids on human monocyte function. J. Clin. Invest. 54: 1337-1343.

11. LoBuglio, A. F., R. S. Cotran, and J. H. Jandl. 1967. Red cells coated with immunoglobulin $\mathrm{G}$ : binding and sphering by mononuclear cells in man. Science (Wash. D. C.). $158: 1582-1585$.

12. Bruckdorfer, K. R., P. A. Edwards, and C. Green. 1968. Properties of aqueous dispersions of phospholipid and cholesterol. Eur. J. Biochem. 4: 506-511.

13. Kellaway, I. W., and L. Saunders. 1967. The solubilization of some steroids by phosphatidyl choline and lysophosphatidyl choline. Biochin. Biophys. Acta. 144: 145-148.

14. Mayer, M. M. 1961. Complement and complement fixation. In Experimental Immunochemistry. E. A. Kabat and M. M. Mayer, editors. C. C. Thomas, Publisher, Springfield, Ill. 2nd edition. 133-240.

15. Schreiber, A. D., and M. M. Frank. 1972. Role of antibody and complement in the immune clearance and destruction of erythrocytes. I. In vivo effects of $\mathrm{IgG}$ and $\operatorname{IgM}$ complement-fixing sites. J. Clin. Invest. 51: 575-582.

16. Kaplow, L. S. 1965. Simplified myeloperoxidase stain using benzidene dihydrochloride. Blood. 26: 215-219.

17. Ruddy, S., and K. F. Austen. 1967. A stoichiometric assay for the fourth component of complement in whole human serum using $\mathrm{EAC}^{\prime} 1 \mathrm{a}^{\mathrm{gp}}$ and functionally pure human second component. J. Immunol. 99: 11621172.

18. Schreiber, A. D., and K. F. Austen. 1974. Hageman factor independent fibrinolytic pathway. Clin. Exp. Immunol. $17: 587-600$.

19. Borsos, T., and H. J. Rapp. 1967. Immune hemolysis: A simplified method for the preparation of $\mathrm{EAC}^{\prime} 4$ with guinea pig or with human complement. J. Immunol. 99: 263-268.

20. Mancini, G., A. O. Carbonara, and J. F. Heremans. 1965. Immunochemical quantitation of antigens by single radial immunodiffusion. Immunochemistry. 2: 235-254.

21. Jandl, J. H. 1955. Sequestration by the spleen of red cells sensitized with incomplete antibody and with metallo-protein complexes. J. Clin. Invest. 34: 912. (Abstr.)

22. Borsos, T., H. R. Colten, J. S. Spalter, N. Rogentine, and H. J. Rapp, 1968. The $\mathrm{C}^{\prime} 1 \mathrm{a}$ fixation and transfer test: examples of its applicability to the detection and enumeration of antigens and antibodies at cell surfaces. J. Inimunol. 101: 392-398.

23. Borsos, T., and H. J. Rapp. 1965. Hemolysin titration based on fixation of the activated first component of complement. Evidence that one molecule of hemolysin suffices to sensitioe on erythrocyte. I. Immunol. 95: 559-566.

24. Rosse, W. F. 1971. Quantitative immunology of immune hemolytic anemia. I. The fixation of $\mathrm{C} 1$ by autoimmune antibody and heterologous anti-IgG antibody. J. Clin. Invest. 50: 727-733.

25. Borsos, T., and E. J. Leonard. 1971. Detection of bound C3 by a new immunochemical method. J. Immunol. 107: 766-771.

26. Logue, G. L., W. F. Rosse, and J. P. Gockerman. 1973. Measurement of the third component of complement bound to red blood cells in patients with the cold agglutinin syndrome. J. Clin. Invest. 52: 493-501.

27. Atkinson, J. P., and M. M. Frank. 1974. Studies on the in vivo effects of antibody. Interaction of $\operatorname{IgM}$ antibody and complement in the immune clearance and destruction of erythrocytes in man. J. Clin. Invest. 54: 339348.

28. Böyum, A. 1968. Isolation of mononuclear cells and granulocytes from human blood. Isolation of mononuclear cells by one centrifugation, and of granulocytes by combining centrifugation and sedimentation at $1 \mathrm{~g}$. Scand. J. Clin. Lab. Invest. Suppl. 97. 21: 77-89.

29. Cooper, R. A., E. C. Arner, J. S. Wiley, and S. J. Shattil. 1975. Modification of red cell membrane structure by cholesterol-rich lipid dispersions. A model for the primary spur cell defect. J. Clin. Invest. 55: 115126.

30. Shattil, S. J., R. Anaya-Galindo, J. Bennett, R. W. Colman, and R. A. Cooper. 1975. Platelet hypersensitivity induced by cholesterol incorporation. J. Clin. Invest. 55 : 636-643.

31. van Furth, R. 1970. Origin and kinetics of monocytes and macrophages. Semin Hematol. 7: 125-141.

32. Bilbey, D. L. J., and T. Nicol. 1958. Effect of various natural steroids on the phagocytic activity of the reticuloendothelial system. Nature (Lond.). 182: 674.

33. Vernon-Roberts, B. 1969. The effects of steroid hormones on macrophage activity. Int. Rev. Cytol. 25: 131159.

34. Gigli, I., and R. A. Nelson, Jr. 1968. Complement dependent immune phagocytosis. I. Requirements for $C^{\prime} 1$, $\mathrm{C}^{\prime} 4, \mathrm{C}^{\prime} 2, \mathrm{C}^{\prime} 3$. Exp. Cell Res. 51: 45-67.

35. Ruddy, S., and K. F. Austen. 1971. C3b inactivator of man. II. Fragments produced by $\mathrm{C} 3 \mathrm{~b}$ inactivator cleavage of cell-bound or fluid phase C3b. J. Immunol. 107: 742-750.

36. Ross, G. D., M. J. Polley, E. M. Rabellino, and H. M. Grey. 1973. Two different complement receptors on human lymphocytes. One specific for $\mathrm{C} 3 \mathrm{~b}$ and one specific for C3b inactivator-cleaved C3b. J. Exp. Med. 138: 798-811.

37. Ross, G. D., and M. J. Polley. 1974. Human lymphocytes and granulocyte receptors for the fourth component of complement (C4) and the role of granulocyte receptors in phagocytosis. Fed. Proc. 33: 759. (Abstr.)

38. Bokisch, V. A., and A. T. Sobel. 1974. Receptor for the fourth component of complement on human B lym- 
phocytes and cultured human lymphoblastoid cells. $J$. Exp. Med. 140: 1336-1347.

39. Huber, H., M. J. Polley, W. D. Linscott, H. H. Fudenberg, and H. J. Müller-Eberhard. 1968. Human monocytes: distinct receptor sites for the third component of complement and for immunoglobulin G. Science (Wash. D. C.). 162: 1281-1283.

40. Mantovani, B., M. Rabinovitch, and V. Nussenzweig. 1972. Phagocytosis of immune complexes by macrophages. Different roles of the macrophage receptor sites for complement (C3) and immunoglobulin (IgG). J. Exp. Med. 135: 780-792.

41. Atkinson, J. P., and M. M. Frank. 1974. Complementindependent clearance of IgG-sensitized erythrocytes: inhibition by cortisone. Blood. 44: 629-637.

42. Mollison, P. L. 1970. The role of complement in antibody-mediated red-cell destruction. Br. J. Haemotol. 18: 249-255.

43. Willmer, E. N. 1961. Steroids and cell surfaces. Biol. Rev. (Camb.). 36: 368-398.

44. Graham, J. M., and C. Green. 1969. The binding of hormones and related compounds by normal and cholesterol-depleted plasma membranes of rat liver. Biochem. Pharmacol. 18: 493-502.

45. Bruckdorfer, K. R., J. M. Graham, and C. Green. 1968. The incorporation of steroid molecules into lecithin sols, $\beta$-lipoproteins and cellular membranes. Eur. J. Biochem. $4: 512-518$.

46. Weissmann, G., and L. Thomas. 1963. Studies on lysosomes. II. The effect of cortisone on the release of acid hydrolases from a large granule fraction of rabbit liver induced by an excess of vitamin A. J. Clin. Invest. 42 : 661-669.

47. Sessa, G., and G. Weissmann. 1968. Phospholipid spherules (liposomes) as a model for biological membranes. J. Lipid Res. 9: 310-318.

48. DeVenuto, F., D. F. Ligon, D. H. Friedrichsen, and H. L. Wilson. 1969. Human erythrocyte membrane uptake of progesterone and chemical alterations. Biochim. Biophys. Acta. 193 : 36-47.

49. Rinehardt, J. J., A. L. Sagone, S. P. Balcerzak, G. A. Ackerman, and A. F. LoBuglio. 1975. Effects of corticosteroid therapy on human monocyte function. $N$. Engl. J. Med. 292: 236-241.

50. Webel, M. L., R. E. Ritts, Jr., H. F. Taswell, J. V. Donadio, Jr., and J. E. Woods. 1974. Cellular immunity after intravenous administration of methylprednisone. J. Lab. Clin. Med. 83: 383-392.

51. Peterson, R. E., J. B. Wyngaarden, S. L. Guerra, B. B. Brodie, and J. J. Bunim. 1955. The physiological disposition and metabolic fate of hydrocortisone in man. J. Clin. Invest. 34 : 1779-1794. 